\title{
CONSULTING SUPPORT OF THE PROJECT MANAGEMENT DEVELOPMENT IN CONDITIONS OF SOCIETY INFORMATIZATION
}

\begin{abstract}
The article justifies the necessity of changing the management paradigm in the emerging information society. It is proved that project management is a determinant factor in cooperation of businesses during globalization. The processes of consulting environment formation as the basis of information support and the expansion of the project management application scope are analyzed. There are proposed measures to improve the project management methodology and to promote its dissemination.
\end{abstract}

Key words: project management, businesses, ecosystem, information infrastructure, information society, information.

Problem setting. The emerging information society is characterized by dynamic quality reforms of all industries; the process is accompanied by the formation of fundamentally different operation environment features of new businesses. These changes in organizing business activities are focused on a wide deployment of multi-vector information consulting environment that initiates and supports innovation, and provides a wide range of additional consultancy services. This environment may include classic business incubators, regional industrial zones, export-oriented zones, scientific (technological) parks, and numerous consulting organizations. In this environment effective standardized management methods based on project management tools are not only widely used but also are being further developed. An important role is played by the various Projects Management Associations - non-profit organizations. There is an acute need in mass dissemination and application of advanced management techniques. Thus, special efforts are now being put into the development of effective standardized methods of management, including project management, their accounting features and trends of changes being caused by the emerging information society.

Analysis of recent research and publications. In modern economic literature project management models and methods are widely studied; domestic and foreign experience of its application with regard to particular industries characteristics is reviewed. The results of fundamental research of project management application are presented in numerous works of domestic and foreign scientists and economists such as L. P. Batenko, S. D. Bushuyev, V. Y'. Voropayev, I. V. Kononenko, I. S. Kalenyuk, I. J. Mazur, L. V. Nozdrina, V. Savchuk, V. A. Rach, G. Tarasyuk, I. V. Chumachenko, O. O. Chykarenko, M. L. Razu, V. D. Shapyro, Yu. P. Sharov [1-12]. But there arises the issue concerning peculiarities of project management application by new businesses in the emerging information society that promotes cooperation and rejects tough competition. An ecosystem may be taken as an example. Within an ecosystem, cooperation is developing well and is consistent with the strategy of smoothing competition [13], (for example, in various functional areas, market sectors, countries), which allows business entities to use freely the competitive strengths of opposing competitive concepts in solving a number of mutual urgent tasks. Thus, methods of applying peculiarities of project management by new businesses in the emerging information society require further study.

Setting goals. The main purpose of the article is to develop modern approaches to the application of project management in the emerging information society with regard to advanced businesses development. In terms of this, it is necessary to conduct:

- analysis of tendencies in changing management aspects in conditions of developing advanced business relations;

- study of the role of project management in the the emerging information society;

- evaluation of the of consulting environment level to increase the scope of project management development and implementation.

\section{The main material presentation}

1. Change of the management paradigm in the emerging information society. Forming and 


\section{N. I. Chukhrai, I. I. Novakivsky}

dynamic updating of businesses have become a typical feature of the emerging information society at the beginning of the XXI century. The current stage of economic relations involves formation of new market spaces to avoid mutually destructive competition and improve constructive relations in an open market environment, thus ensuring stable growth and efficient use of businesses potential. Communications globalization may become an alternative to expansion of foreign monopolistic businesses, the nature of communication globalization being not the dominance of one or more poles but an equal dialogue of all participants in order to preserve species diversity and freedom of choice of social and economic management models.

The essence of these transformations is that different market participants are functionally linked to one another by branched information flows which accompany the processes of forming and meeting (directly or indirectly) the demand for products / services. As a result, an extensive information infrastructure is dynamically developing, the main objective of it being information flows servicing. In the process of information infrastructure development, parallelly to its capacity increase, there are being intensively developed the related intellectually independent consulting services hubs. This enhances the possibilities of diverse businesses to collaborate and contributes to smoothing the competitive confrontation.

In general, we can distinguish a number of changes in the management systems of businesses, among them being the following:

- use of a single information and communication space of the country for integration in frames of regional, national or international structures;

- systematic introduction of advanced information and communication technologies in the field of enterprise activities;

- transition from information resources management to management of information capital;

- increase of the role of knowledge in information and communication infrastructures at macro- and micro- levels;

- increase of importance of human potential in businesses activities, the emphasis in personnel evaluation being made on qualification, professionalism, creativity, and ability to learn;

- focus on introduction of collective decision-making systems with possible involvement of external expertise.
Changes in emphasis occurring in management systems are primarily manifested at the level of information communications, in forming innovative businesses. The most effective tool of businesses coordinated activities and development is introduction of advanced management information systems where methods of project management are widely used [7]. These changes are due to the fact that in the emerging information society efforts of active businesses should be concentrated on the effective use of knowledge in management and on the democratization of decision-making processes.

As a matter of fact, mutual respect, solidarity and cooperation, openness and partnership create a fundamentally different plane of interaction between partner - companies, manufacturers and customers, as well as between competing companies. Qualitative field of interaction within the internal network creates new understanding of higher values in the economy, opens new perspectives which give rise to the formation of a new economic culture. One of the most valuable results of a collaborative qualitative ecosystem is the formation of "economic patriotism" that is, the introduction of the ancient model " sviy do svoho po svoie (one goes to oneself for one's own)".

Development of new businesses may occur, for example, in the form of a consumer ecosystem which operates within the clearly defined macromarketing environment and may be completely modified due to the appearance of continuous technological innovation. The concept "an ecosystem of entrepreneurship" was introduced in 1996 by a psychologist John. F. Moore from Harvard University in his book "The Death of Competition" [13]. Similar to nature, an ecosystem in a market economy is seen as a complex group of companies and customers, suppliers, competitors, distributors who influence business individuals and groups as well as partners who benefit from each other. In the ecosystem of buyers the market activities (investments, joint development of products, market communication, logistics and transactions) are performed and controlled not only by suppliers but also by consumers. During the ecosystem functioning there arises the necessity to synchronize the efforts of its members who participate in creating innovations and their introduction to the market. In order to limit or avoid direct confrontation of enterprises in the ecosystem it is possible to look for new points of 


\section{Consulting support of the project management development in conditions of society informatization}

differentiation, new positioning, try to attract new customers and so on. For example, we may note that some restaurants and souvenir shops in Lviv cooperate with social bakeries, candle shops, furniture stores (commercial projects for disabled people) where prices are generally lower, and the quality of products is high.

Compliance with new ethical norms and rules of businesses interaction in the information society involves interaction based on the following principles: mutual respect; partnership and openness; solidarity; producer and consumer cooperation; consideration of socially important projects; economic patriotism.

Building relationships is a quality indicator of a social ecosystem and its maturity. For example, IT companies in Lviv are united in a cluster of information technologies and services for the development of the industry in the region. Through solidarity in the coordination of regional and national projects and programs businesses received the opportunity to influence the formation of national legal framework or elaboration of regional plans etc. So, this IT-cluster is a coherent business structure with a certain image that should be respected. In general, application of project management principles in distributed businesses opens up entirely new prospects for them.

\section{Project management as a determining} means of cooperation in the emerging information environment.

The formation of new businesses activates the formation of a new paradigm of their interaction with each other and with the external environment in general. While in the postindustrial environment the emphasis in management was placed on the organization of transparent material flows, in the information society, this interaction takes place at the level of intellectual exchange, which requires the use of high-level language of communication adopted by business entities. We may distinguish the fundamental changes of management paradigm in the emerging information society which are schematically shown in Fig. 1.
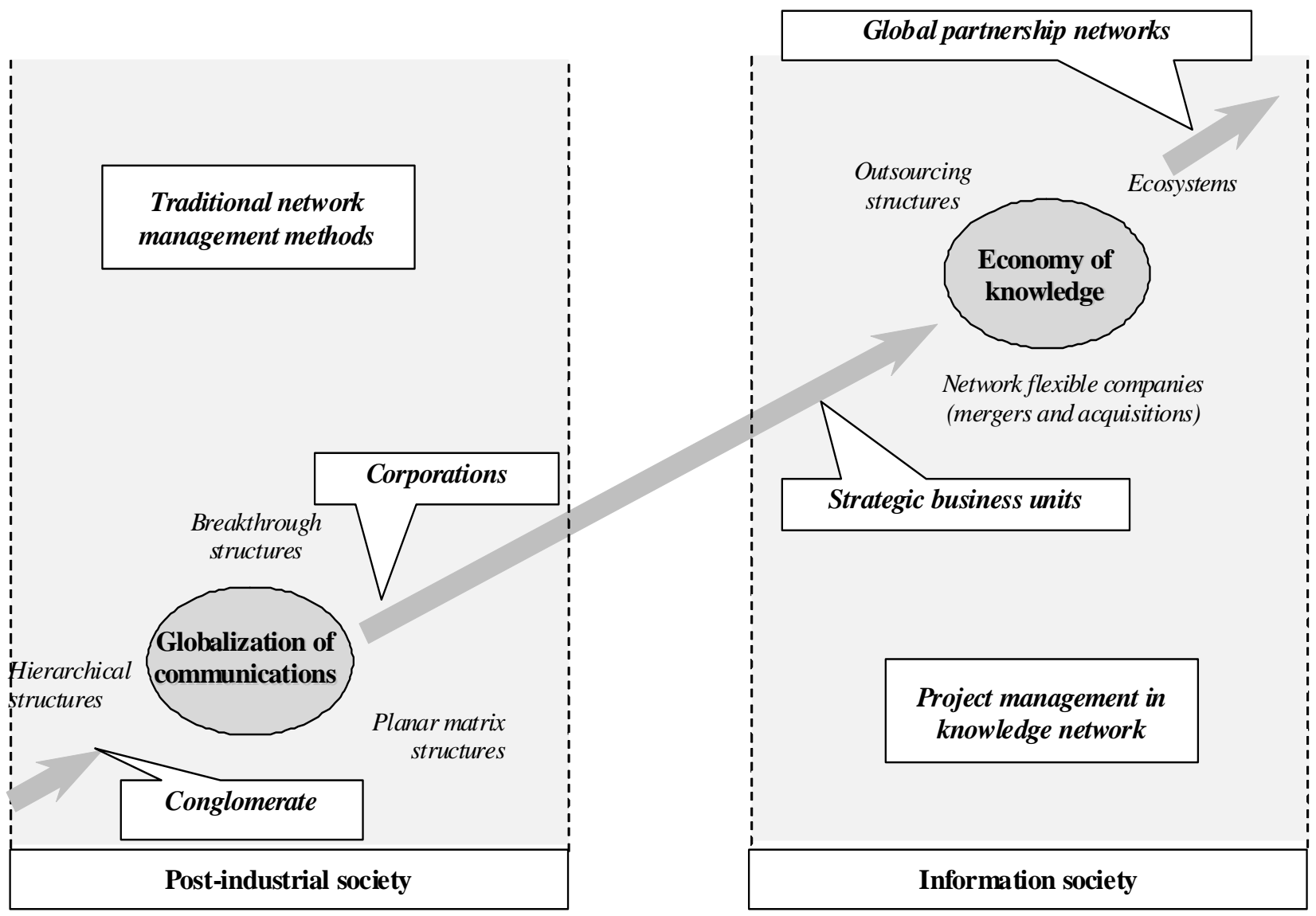

Fig. 1. The essence of management paradigm shift in modern conditions

Source: The authors' development 


\section{N. I. Chukhrai, I. I. Novakivsky}

Expanding the scope of project management application is explained as follows:

- On the one hand, nowadays it is natural to consider the entire chain of goods / services production as a whole - from the use of necessary resources to products consumption and waste utilization. Matching interests of market participants is primarily manifested in increasing interdependence between them and the dual nature of their interaction, which is consistent within the set of projects and programs, i.e. combining the benefits of coordinated actions and diminishing the loss from competition. Open global management technologies through applying project management multiply direct and hidden profits of businesses.

- On the other hand, the life cycle of products / services being reduced, the multi-vector activities at the operational and tactical levels become the direct object of management and it is natural to support these activities within a set of projects and programs. The turbulence of the external environment generates random fluctuating changes in businesses activities that require reasonable correlating software-caused impact by means of project management. Searching for temporary niche with a satisfactory level of competition, businesses at the market want to accommodate in the most comfortable way. Thus, businesses organizational sustainability is increasing, which refers not to strength or consistency of organization elements (structure, processes, management, relations and so on) but to the ability to participate in various activities with temporary or long-term benefits.

The following are the basic principles of project management: evolutionary and phased development; compliance with ethics and rules; synchronization of management development process with the development of national economy; involvement of the general public to the modern culture of projects management.

The presence and efficient use of projects management systems allows diverse business structures significantly reduce risks and increase the likelihood of successful projects realization. According to statistics, only $37 \%$ of the projects are successful. In enterprises that use methods of project management, $72 \%$ of projects are successful; in those that do not use these methods - only $23 \%$. We should keep in mind that even when projects are successfully implemented without a clear project management system built on the enthusiasm and dedication of the project organizers the results are achieved with much higher costs.

This is confirmed by studies of 30,000 applied projects in large, medium and small interdisciplinary companies in the USA, which were conducted by Standish Group company since 1994 (Fig. 2).

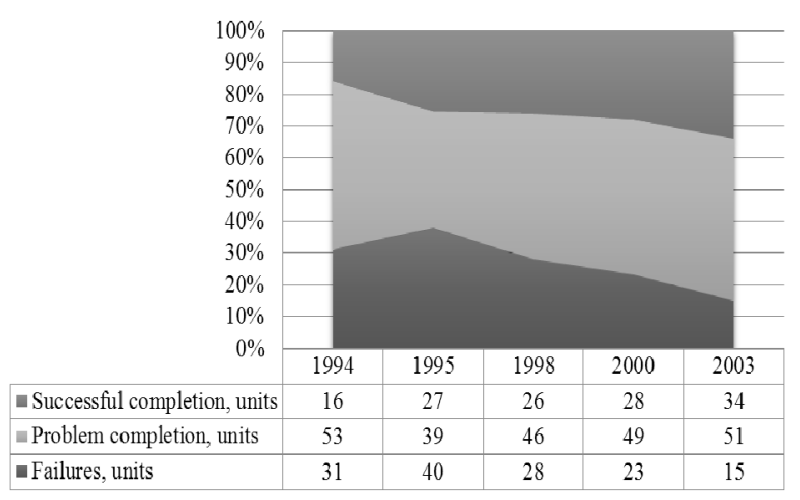

Fig. 2. The study of performance dynamics

Processed source: The Standish Group International, "10th Annual (2003) CHAOS Report," CHAOS Chronicles 3 (2003): 406.

Application of design approach in businesses management allows:

- to plan the work on the project and coordinate project activities;

- to attract outside funding and effectively use business own funds;

- to minimize costs;

- to create a project team and effectively manage it;

- to reduce risks by minimizing the environment uncertainty of project realization through the use of project management in the network of expertise.

3. Formation of the consulting environment as a base for broadening the scope of applying project management.

To promote and effectively implement a wide range of innovations, methods of project management have been widely applied. This, in turn, caused formation of advanced distributed environment of consulting services. A wide range and classification of consulting services is presented in Table 1. 
Classification of consulting services

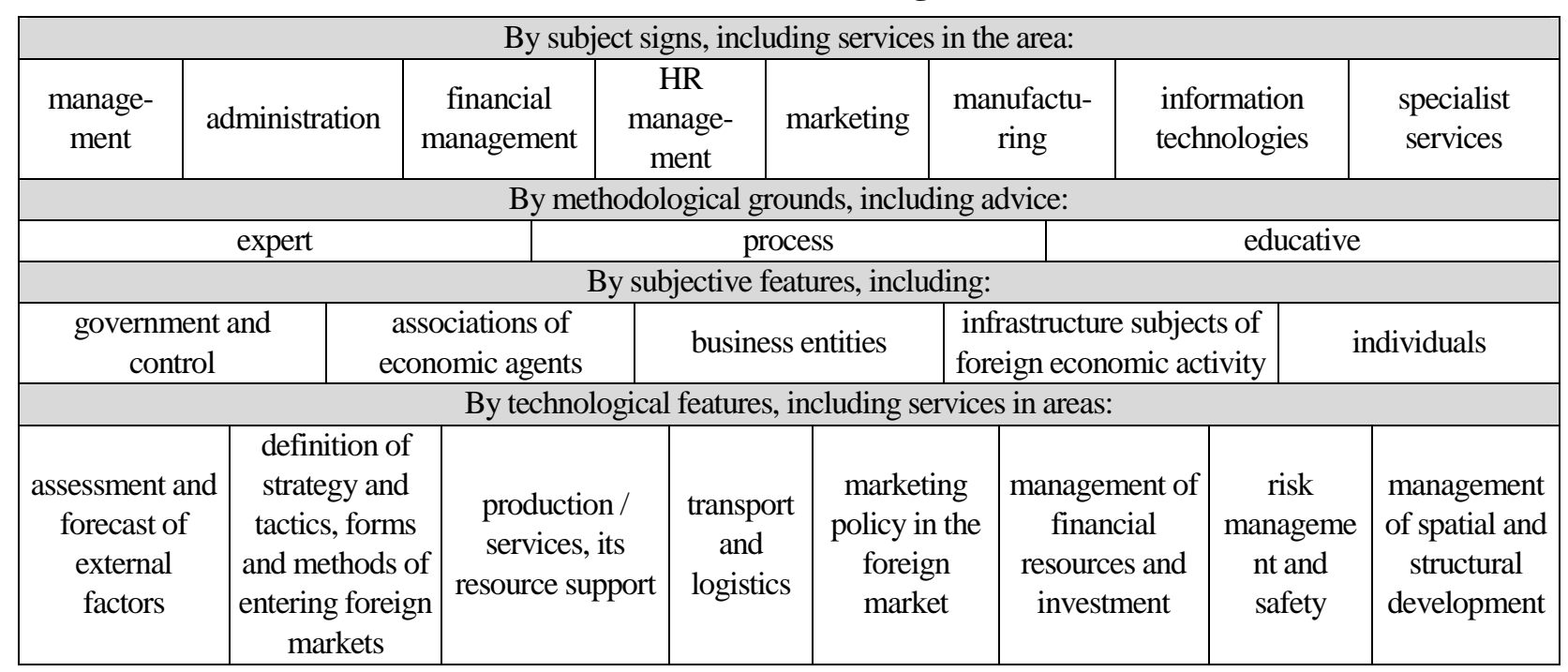

* Source: Authors'development.

In many businesses (construction, software development, audit and consulting, advertising and marketing) project management has become the core of organizations activities. On the one hand, entirely new needs and business opportunities as well as requirements of cooperation in the environment, particularly in international activities, have become the stimulus for project management application. On the other hand, focus on managing the short product life cycle and the need to maximize the use of available resources became relevant for the most of domestic organizations and companies.

Talking about the development of project management in Ukraine since 1988 we should first of all mention Ukrainian Association of Project Management "UkrNet" (Ukrainian Project Management Association "UPMA"). The main tasks of UKRNET are: development of project management culture with the use of modern methods and information systems, organization of international certification of professional project managers based on IPMA standards, publication of literature on project management, consulting and training courses etc.

In general, PMI as organization and certification PMP is recognized by many nongovernment and government organizations as well as by various businesses around the world. The results of data analysis PMI Credential Registry, PMI-PMP confirms importance of specialists training in Ukraine. Dynamics of PMP specialists training and its forecast are shown in Fig. 3.

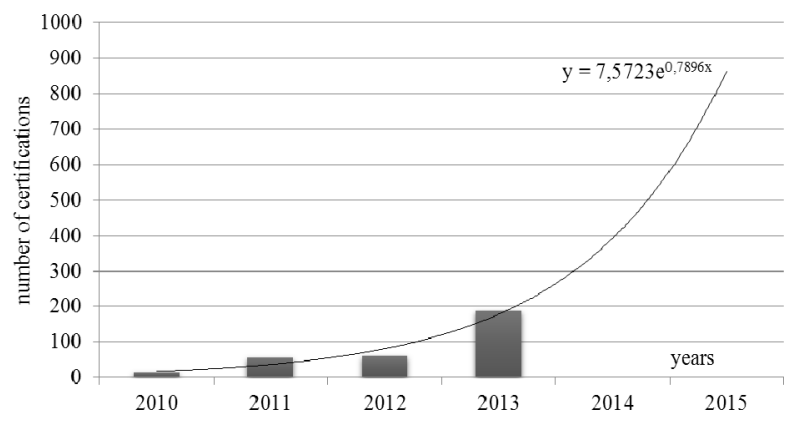

Fig. 3. Analysis of the number and forecast of certifications in Ukraine issued by PMI-PMP

Processed Source: P. Tarakanova IT-certification in Ukraine: Analysis and forecasts for 2014 / Pauline Tarakanova

http://dou.ua/lenta/articles/it-sertificationin-ukraine-2014/

As we can see, there is exponential growth in the number of specialists in the field of project management. However, to achieve the required number of specialists in Ukraine in the field of project management it is necessary to make great efforts. We should note that in developed countries the number of certified specialists is more than tens of thousands.

But for UKRNET, there are other organizations working towards improving project management methodology in Ukraine: Association "Ukrkonsalting"; SE "Ukrpromzovnishexpertyza" SE "Ukrinvestexpertyza"; "Technology and investment consulting (TIKON)" and others. These and other non-profit organizations, established by 


\section{N. I. Chukhrai, I. I. Novakivsky}

practicing project managers, play a significant role in the systematic development and implementation of project management.

Besides, the scope of project management in developed countries was supported through the development of business incubators, regional industrial zones, export-oriented zones, research (technology) parks and numerous consulting organizations. So, in Ukraine similar consulting facilities are developed, including more than 20 business incubators. However, only about 10 of them are active, among them: Bilotserkivskyi, Slavutyckyi, Ternopilskyi, Lvivskyi, IvanoFrankivskyi, Donetskyi, Kharkivskyi. Ukrainian Association of Business Incubators and Innovation Centers has practical experience in the creation and development of business incubators, business support centers in Ukraine, comprehensive international contacts, organization experience and conferences, seminars organization at international levels. Though economic conditions are unfavourable these structures continue to work due to government support. As funding is insufficient, their effectiveness in Ukraine remains low.

At the same time in Ukraine commercial consulting organizations are being efficiently created initiating major changes in the development of promising businesses through introduction of information systems based on project management. For example, LEO Consulting, SBS Consulting, Itera Consulting, "Advice Group" consulting company, J \& L Consulting, LLC "Project Management Business Consulting" and others, regular clients of which are businesses from various industries. Many of them begin with the development and implementation of various software. The major tasks of intensification of economic development of Ukraine that should be solved with the help of project management are as follows:

- ensuring business transparency through unification and standardization of business management;

- increasing businesses responsibility both internally and externally;

- carrying on modernization and intensification of all branches of Ukrainian economy on the basis of the general principles of management;

- multi-vector development of various Ukrainian industries that will promote sustainable and dynamic development of the Ukrainian economy as a whole;

- increasing education quality standards.
We may note that project management national models and standards are not static and are developing rapidly. Approximately once in every four years PMI updates the standard PMBOK®. The most common version of the document is dated 2000 and the latest version - The Guide to the PMBOK 5-th Edition - 2013. Due to the international network in the field of project management support processes of international cooperation are simplified, comparable development of countries economies is provided due to adherence to national and international standards. This is confirmed by the fact that under the ISO a new project committee ISO / TC 236 "Project Management" was simultaneously created. Due to its efforts ISO 21500: 2012 was introduced. We may summarize that the main areas of research in the field of project management are:

- development of project management within professional associations in the field of projects management;

- development of project management methodology and performance improvement in specific areas of application through businesses initiatives.

Providing innovative development and promotion of progressive businesses requires the formation and maintenance of modern system of project management and training based on the knowledge network. Only continuous development of these components in accordance with national interests and demands of the present moment, long-term strategy, civilization and geopolitical objectives may provide intensive economic growth in Ukraine.

Conclusions. We can conclude that an efficient economy in terms of the emerging information society requires the formation of a developed business environment open to international cooperation. Obviously, the determinant of this task will be the formation of a distributed information infrastructure as a catalyst for the use of project management techniques.

The development of the main components of the innovation and project management should be implemented through balanced integration of the world experience, the country specifics and the national culture of management.

To achieve this goal it is proposed to focus on the following objectives:

- to develop a national network of knowledge for distance learning or providing consulting 
services for various population groups (civil servants, teachers, university students, leaders of businesses etc.) using active learning methods, coaching and evaluation techniques, joint consultation of participants, exchange of experience in implementing similar projects, workshops of professionals or managers with the experience in complex projects, online conferences;

- to foster the application range of project management techniques, facilitate its adaptation to specifics of Ukrainian industries;

- to create a favorable legal framework for the development and application of advanced project management techniques;

- to open a permanent network of experts knowledge for the improvement of specialists qualification and project management development.

The mutual enrichment of national and international management cultures and technologies through a balanced approach with the account of regional features may provide real efficiency of the national economy and its projects. It is appropriate to recall the experience of China, which efficiently solves the tasks of its national economy development.

Prospects for further research. It is supposed to examine trends in interpenetration of knowledge in project management related to the adjacent spheres of management through the development of expert knowledge networks as well as to expand the use of artificial intelligence in the field of project management.

\section{References}

1. Бушуев С. Д. Управление проектами. Основы профессиональных знаний и система оценки компетенции проектных менеджеров (National Competence Baseline, NCB UA Version 3.1) / С. Д. Бушуев, Н. С. Бушуева- Изд. 2-е. - К.: ІРІДІУМ, 2010. - 208 c.

2. Каленюк I. С. Сутність і показники ефективності проекту / І. С. Каленюк, Н. І. Холявко // Науковий вісник ЧДІЕУ. - 2009. - № 3 (4). C. 4-13.

3. Кононенко И. В. Оптимизация содержания проекта по критериям прибыль, время, стоимость, качество, риски / И. В. Кононенко, М. Э. Колесник // Восточно-европейский журнал передовых технологий. - 2012. - № 1/10 (55). C. 13-15.

4. Кононенко И. В. Модель и метод оптимизачии портфелей проектов предприятия для плано- вого периода / И. В. Кононенко, К. С. Букреева // Восточно-Европейский журнал передовых технологий. - 2010. - №1/2 (43). - С. 9-11.

5. Кононенко И. В. Прогнозное обеспечение разработки региональной программь развития информачионных технологий / И. В. Кононенко, А. Н. Репин Форум "Взгляд в будущее, развитие Харьковского региона через информаиионные технологии и построение информационного общества" Сборник докладов. Харьков, 2006. C. 56-60.

6. Мазур И. Й. Управление проектами. Справочник для профессионалов / И. Й. Мазур, В. Д. Шапиро и др. - М.: Высшая школа, 2001. - 875 c.

7. Милошевич Д. Набор инструментов для управления проектами / Д. Миломевич /Пер. с англ. Мамонтова Е. В.; под ред. Неизвестного С. И. М.: Компания АйТи; ДМК Пресс, 2008. - 729 с.

8. Ноздріна Л. В. Управління проектами: підручник / Л. В. Ноздріна, В. І. Ящук, О. І. Полотай / за заг. ред. Л. В. Ноздріної. - К.: Центр учбової літератури, 2010. -432 c.

9. Разу М. Л. Управление программами и проектами / М. Л. Разу, В. И. Воропаев. - М.: ИНФРА-М, 2000.

10. Рач В.А. Базові положення тріадної парадигми управління проектами / В. А. Рач // Управління проектами: стан та перспективи: Матеріали 7-ї Міжнародної науково-практичної конференції. - Миколаїв: НУК, 2011. - С. 267-270.

11. Рач В. А. Управління проектами: практичні аспекти реалізаиії стратегій регіонального розвитку: навч. посіб. / В. А. Рач, О. В. Россошанська, О. М. Медведєва; за ред. В. А. Рача. K.: “К. I. C. ", 2010. -276 c.

12. Чумаченко И. В. Формирование холистической иенности инновачионных проектов и программ / И. В. Чумаченко, Н. В. Доценко // Східноєвропейський журнал передових технологій. 2011. - № 1/6 (49). - C. 13-16.

13. Чухрай Н. I. Кооперениія як стратегія функиіонування підприємств на ринку інновачій / H. I. Чухрай // Восточно-европейский журнал передовых технологий "Интегрированное стратегическое управление, управление проектами и программами". - № 1/3 (43). - Харків: 2010. - С. 34-37.

\section{Reference list Bibliography (transliterated)}

1. Bushuev S. D. Upravlenye proektamy. Osnovy professyonal'nyh znanyj y systema ocenky kompetencyy proektnyh menedzherov (National Competence Baseline, NCB UA Version 3.1) / S. D. Bushuev, N. S. Bushueva- Yzd. 2-e. - K.: IRIDIUM, 2010. - 208 s. 


\section{N. I. Chukhrai, I. I. Novakivsky}

2. Kalenjuk I. S. Sutnist' i pokaznyky efektyvnosti proektu / I. S. Kalenjuk, N. I. Holjavko // Naukovyj visnyk ChDIEU. - 2009. - № 3 (4). - S. 4-13.

3. Kononenko $Y$. V. Optymyzacyja soderzhanyja proekta po kryteryjam prybyl', vremja, stoymost', kachestvo, rysky / Y. V. Kononenko, M. E. Kolesnyk // Vostochno-evropejskyj zhurnal peredovyh tehnologyj. - 2012. - №1/10 (55). - S. 13-15.

4. Kononenko Y. V. Model' y metod optymyzacyy portfelej proektov predpryjatyja dlja planovogo peryoda / Y. V. Kononenko, K. S. Bukreeva // Vostochno-Evropejskyj zhurnal peredovyh tehnologyj. - 2010. - № 1/2 (43). - S. 9-11.

5. Kononenko $Y$. V. Prognoznoe obespechenye razrabotky regyonal'noj programmy razvytyja ynformacyonnyh tehnologyj / Y. V. Kononenko, A. N. Repyn Forum "Vzgljad v budushhee, razvytye Har'kovskogo regyona cherez ynformacyonnye tehnologyy $y$ postroenye ynformacyonnogo obshhestva" Sbornyk dokladov. Har'kov, 2006. - S. 56-60.

6. Mazur Y. J. Upravlenye proektamy. Spravochnyk dlja professyonalov / Y. J. Mazur, V. D. Shapyro y dr. - M.: Vysshaja shkola, 2001. - 875 s.

7. Myloshevych D. Nabor ynstrumentov dlja upravlenyja proektamy / D. Myloshevych / Per. s angl. Mamontova E. V.; pod red. Neyzvestnogo S. Y. M.: Kompanyja AjTy; DMK Press, 2008. - 729 s.
8. Nozdrina L. V. Upravlinnja proektamy Pidruchnyk/ L. V. Nozdrina, V. I. Jashhuk, O. I. Polotaj /Za zag. red. L. V. Nozdrinoi'. - K.: Centr uchbovoi' literatury, 2010. - $432 \mathrm{~s}$.

9. Razu M. L. Upravlenye programmamy y proektamy / M. L. Razu, V. Y. Voropaev - M.: YNFRA-M, 2000.

10. Rach V. A. Bazovi polozhennja triadnoi' paradygmy upravlinnja proektamy / V. A. Rach // Upravlinnja proektamy: stan ta perspektyvy: Materialy 7- $i^{\prime}$ Mizhnarodnoi' naukovo-praktychnoi' konferencii'. Mykolai'v: NUK, 2011. - S. 267-270.

11. Rach V. A. Upravlinnja proektamy: praktychni aspekty realizacii' strategij regional'nogo rozvytku: navch. posib. /V. A. Rach, O. V. Rossoshans'ka, O. M. Medvedjeva; za red. V. A. Racha. - K.: “K. I. S.", 2010. - 276 s.

12. Chumachenko Y. V. Formyrovanye holystycheskoj cennosty ynnovacyonnyh proektov y programm / Y. V. Chumachenko, N. V. Docenko // Shidnojevropejs'kyj zhurnal peredovyh tehnologij. 2011. - № 1/6 (49). - S. 13-16.

13. Chuhraj N. I. Kooperencija jak strategija funkcionuvannja pidpryjemstv na rynku innovacij / N. I. Chuhraj // Vostochno-evropejskyj zhurnal peredovyh tehnologyj "Yntegryrovannoe strategycheskoe upravlenye, upravlenye proektamy y programmamy”. - № 1/3 (43). - Harkiv: 2010. - S. 34-37. 